\title{
Bone densitometry by radiofreequency echographic multi-spectrometry (REMS) in the diagnosis of osteoporosis
}

\section{ABSTRACT}

The paper summarises the present knowledge of the new bone densitometry method called radiofrequency echographic multi-spectrometry (REMS). This ultrasound-based approach enables the evaluation of bone mineral density (BMD) in the hip and the lumbar spine. During REMS densitometry, a fully automatic algorithm performs a series of spectral and statistical analyses involving both echographic images and corresponding "raw" (unfiltered) radiofrequency signals. This provides the identification of the region of interest
(ROI) and the calculation of standard densitometric parameters: BMD, T-score and Z-score. Nondiagnostic scans and artifacts are automatically excluded by the algorithm, reducing the risk of false results. A recently published multi-center study has demonstrated high diagnostic sensitivity, specificity and accuracy of this innovative method in the diagnosis of osteoporosis. To the authors' best knowledge, this is the first Polish paper on REMS densitometry.

Forum Reumatol. 2019, tom 5, nr 2: 81-88

Key words: osteoporosis; bone density; ultrasonography

\section{INTRODUCTION}

Osteoporosis is a systemic skeletal disease characterised by low bone mass and microarchitectural deterioration of bone tissue, which results in an increase in bone fragility and susceptibility to fractures [1]. Osteoporotic fractures are usually the result of low-energy trauma - such as a fall from one's own height — or they occur without any identifiable trauma. They are a frequent cause of pain, disability, reduced quality of life and increased mortality, which makes osteoporosis a major social issue. It was estimated that in 2010, in the European Union alone, 22 million women and 5.5 million men met the densitometric criterion of osteoporosis, and the number of new fragility fractures was 3.5 million [2]. The aim of osteoporosis treatment is to prevent fractures (the first or subsequent ones), mainly by increasing bone strength and reducing the risk of falls. Due to its long-term asymptomatic clinical course, the diagnosis of osteoporosis is based on an individual fracture risk assessment. Therapeutic decisions are made on the same basis [3].

\section{THE ROLE OF BONE MINERAL DENSITY (BMD) IN THE DIAGNOSIS OF OSTEOPOROSIS}

Bone mineral density (BDM) measured by densitometry is one of the strongest predictors of fracture risk $[4,5]$. The relationship between BMD and an increased fracture risk is as strong as the relationship between hypertension and the risk of stroke [6]. It has been 25 years since an international group of experts, acting with the support of the World Health Organisation, announced a pioneering report on osteoporosis. This document is the source of the densitometric criterion of osteoporosis, which is still used today [7]. The T-
Correspondence address: Piotr Leszczyński, M.D., Ph.D. Department of Rheumatology and Rehabilitation, Poznan University of Medical Sciences e-mail: piotr_leszczynski@wp.pl 
-score value used in the criterion corresponds to the number of standard deviations that distinguishes the BMD assessed in the patient from the average in the reference population of young adults. The indicator calculated analogously, but relative to the reference population matched to the patient in terms of gender and age, is referred to as the $\mathbf{Z}$-score. Replacing the absolute BMD value with the standardized scores was supposed to facilitate the interpretation of results and reduce the influence of the equipment on the densitometry results [8]. On the basis of the T-score value and the history of fractures, authors of the report distinguished four categories:

- normal value ( $\mathrm{T}$-score $\geq-1.0$ )

- osteopenia $(-2.5<\mathrm{T}$-score $<-1)$

- osteoporosis ( $\mathrm{T}$-score $\leq-2.5$ )

- severe osteoporosis ( $\mathrm{T}$-score $<-2.5$ and osteoporotic fracture).

It is important to realize that the quoted report concerned only postmenopausal osteoporosis, and the above categories were to be applied for epidemiological purposes. However, the T-score criterion fell on the fertile soil of the expectations of clinicians, who considered the conceptual definitions of osteoporosis to be practically useless. Under these conditions, by clinical practice, a T-score threshold of $\leq-2.5$ has become a diagnostic criterion. Initially, it was used in the post-menopausal women, but subsequently also in men over 50 years of age $[3,8]$. Contrary to popular belief, the 1994 report did not favour single densitometry method or skeletal site. Three methods, fulfilling the requirements of a good screening test, were suggested: single photon absorptiometry, single-energy X-ray absorptiometry and dual-energy X-ray absorptiometry (DXA). As for the selection of the measured skeletal site, it was to be based on the aim of densitometry or the screening program [7]. It can now be stated that it is only the DXA method that has withstood the test of time, and that the assessment of BMD at the hip or the lumbar spine, referred to as central sites, is of the greatest diagnostic and prognostic value. In these sites particular areas of measurement are distinguished, i.e. the so-called regions of interest (ROI): the femoral neck, the total hip/total proximal femur and the L1-L4 vertebrae $[9,10]$. Out of the categories distinguished in the report only osteoporosis and normal value have remained in use. The concept of 'osteopenia' is not regarded as a clinical category today and, by the original intention of its authors, it should remain an epidemiological one. The criterion of "severe osteoporosis" proved to be useless: in the presence of fractures it is difficult to assess disease severity based on any BMD threshold [3]. Similarly, osteoporosis may be diagnosed in patients with a history of low-energy fracture even if the densitometric criterion is not met. In these cases, however, BMD measurement remains a valuable tool in monitoring treatment [9]. According to the recommendations of the International Society for Clinical Densitometry (ISCD), the T-score value of femoral neck and the "total hip" area in patients of both sexes is calculated using the reference population of Caucasian women aged 20-29 years, established as part of the III National Health and $\mathrm{Nu}-$ trition Examination Survey (NHANES). As for the T-score of the lumbar vertebrae, it is based on the reference database provided by the densitometer manufacturer [10].

\section{DXA AND QUS METHODS}

In the DXA method, the bone mineral content (BMC) is assessed on the basis of the $\mathrm{X}$-ray attenuation value of the examined area, and subsequently the BMD $\left[\mathrm{g} / \mathrm{cm}^{2}\right]$ is calculated by dividing the BMC [g] by the projected bone area $\left[\mathrm{cm}^{2}\right]$. The projected bone area, i.e. the area of the two-dimensional projection of the examined region, serves as a surrogate of its volume. Thus, the BMD value $\left[\mathrm{g} / \mathrm{cm}^{2}\right]$ is not the density in a physical sense $\left[\mathrm{g} / \mathrm{cm}^{3}\right]$ and is sometimes referred to as the areal bone mineral density $[11,12]$. If the bone is fully mineralized, as is the case in osteoporosis, BMD and $\mathrm{BMC}$ values reflect the bone mass [13, 14].

The DXA method, which is considered the gold standard for BMD assessment in clinical practice, is not free from limitations that reduce its screening availability and suitability. The most important limitations of DXA include: a high risk of false negative results, the necessity to be operated by highly qualified personnel, low mobility of the equipment, high costs, the need to position the patient's body in a specific manner, as well as the organisational and legal requirements related to the ionising radiation [14-16]. Hopes for improved osteoporosis detection were put on quantitative ultrasound (QUS), which is free of most of the DXA limitations, but cannot be considered as its alternative. The available QUS techniques operate in a transmission mode, based on ultrasound wave analysis after passing through 
the examined area. In this system, acoustic spectra are assessed for specific quantitative phenomena, which are the effect of ultrasound interaction with the bone tissue. The most frequently analysed parameters include the broadband ultrasound attenuation and the speed of sound. In recent years, there has been an increased interest in backscatter QUS techniques, which are supposed to provide more information concerning the bone microarchitecture. These techniques are based on a quantitative evaluation of echoes that return to the probe as a result of the ultrasonic backscattering from the examined area. Similarly to transmission techniques, QUS backscatter techniques are based on single spectral phenomena such as backscatter coefficient or the spectral centroid shift. Each parameter of this type has its own advantages and limitations. It should be noted that although the acoustic parameters determined in QUS may show a significant correlation with BMD, fracture risk or some features of bone microarchitecture, none of these techniques is equivalent to densitometry. Additionally, the currently available QUS techniques do not make it possible to assess bone parameters at the central sites $[15,17]$.

\section{PRINCIPLE OF THE REMS METHOD}

Radiofrequency echographic multi-spectrometry (REMS) is a response to the limitations of DXA and QUS - it is a new method of quantitative bone assessment, which is the subject of this paper. Although REMS examination is based exclusively on the interaction of ultrasound waves with the bone tissue, it enables the assessment of BMD in $\mathrm{g} / \mathrm{cm}^{2}$ and represents a densitometric measurement comparable to DXA. Evaluation of BMD by REMS is performed at the hip and lumbar spine (L1-L4). For these reasons, REMS densitometry is not included in the QUS group, and its perception in the literature is somehow in opposition to these techniques [15, 17].

A REMS densitometer is a small ultrasound device equipped with a 128-element convex probe with a frequency of $3.5 \mathrm{MHz}$ (Fig. 1). As the proprietary software provides a user interface and diagnostic algorithm, the device must be connected to a computer. In addition to the stationary version, the manufacturer offers a portable kit that includes a densitometer and a laptop in a specially designed suitcase (Fig. 2). This ensures high mobility of the equipment. When a measurement is being performed, the

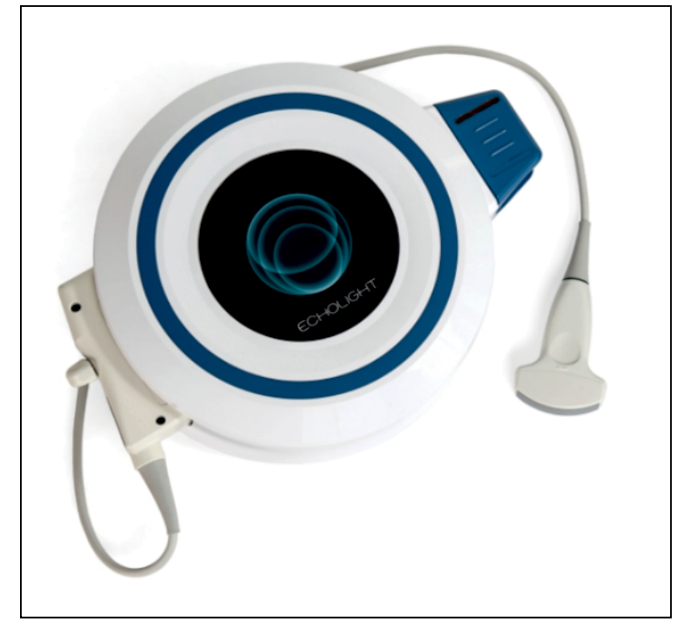

Figure 1. REMS densitometer (Echolight S.p.A., Italy) [18]

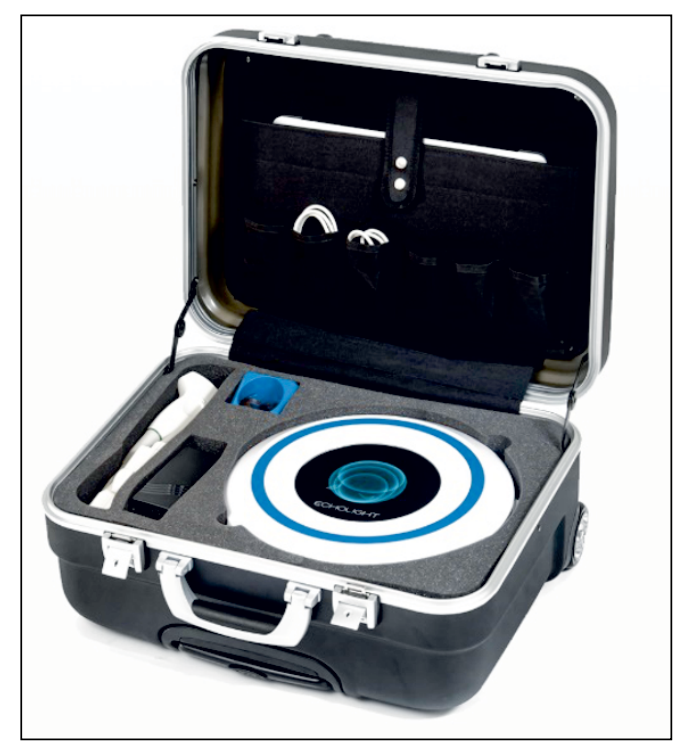

Figure 2. REMS densitometer in a portable set equipped with a laptop (Echolight S.p.A., Italy) [18]

ultrasound signals emitted by the probe are backscattered from the bone tissue towards the probe in the form of echoes. The ultrasound echoes are converted into radiofrequency (RF) electrical signals in the device. The integral analysis of the ultrasound images and the corresponding "raw" (unfiltered) RF signals by an automatic algorithm makes it possible to identify both the bone surface and the corresponding ROI. The ROI spectra are segmented into areas corresponding to the joint cartilage, cortical bone and trabecular bone, with the third one being the only one taken into account in subsequent calculations. Comparison of the ROI spectra with the reference spectral models enables the calculation of the so-called Osteoporosis Score (O.S.), followed 
by a BMD expressed in $\mathrm{g} / \mathrm{cm}^{2}$. In the last stage, a T-score and Z-score are calculated using the NHANES reference database $[16,19,20]$. The test result may also include a 10 -year fracture risk assessment thanks to the integrated Fracture Risk Assessment Tool (FRAX ${ }^{\circledR}$ ) [21]. An important feature of the REMS method is that it automatically verifies whether the spectral features of the tested area correspond with the spectral model of the trabecular bone. If the area is considered to be non-diagnostic or the measurement fails to provide signals of sufficient quality, the operator will not receive the test result, but will need to perform the test again. To obtain the REMS result for the lumbar spine, the correct BMD assessment of at least two vertebrae must be carried out. The automatic algorithm is a significant advantage of the REMS method over DXA, in which the assessment of the measurement reliability depends solely on the operator $[16,19]$.

\section{THE REMS EXAMINATION}

The examination in both central sites is performed on a patient lying on the back, with their limbs freely positioned along the body. A different positioning of the patient's body, e.g. as a result of musculoskeletal or nervous system diseases, is not a contraindication for REMS densitometry. In such cases, a non-standard placement of the probe may enable BMD evaluation, depending on the operator's skill and experience. Altered anatomical relationships may pose a similar challenge (but not a contraindication). The REMS examination starts when the probe is placed over the tested bone. The L1-L4 vertebrae are tested from the abdominal wall side and the hip from the anterior side of the thigh. A thin layer of ultrasound gel is applied to the patient's skin (or the device probe) beforehand. Lumbar vertebrae are evaluated starting from L1 to L4, with the probe being gradually moved along the axis of the spine. The evaluation of a single vertebra lasts 20 seconds and the moment of movement from one vertebra to another is signalled visually and audibly by the device. On the ultrasound screen there are usually two or more vertebral surfaces visible at the same time, but the measurement concerns only the vertebra in the central part of the image. The examination of the hip requires the probe to be placed parallel to the femoral head-neck axis. After a simultaneous visualisation of the femoral head, neck and major trochanter is provided, the
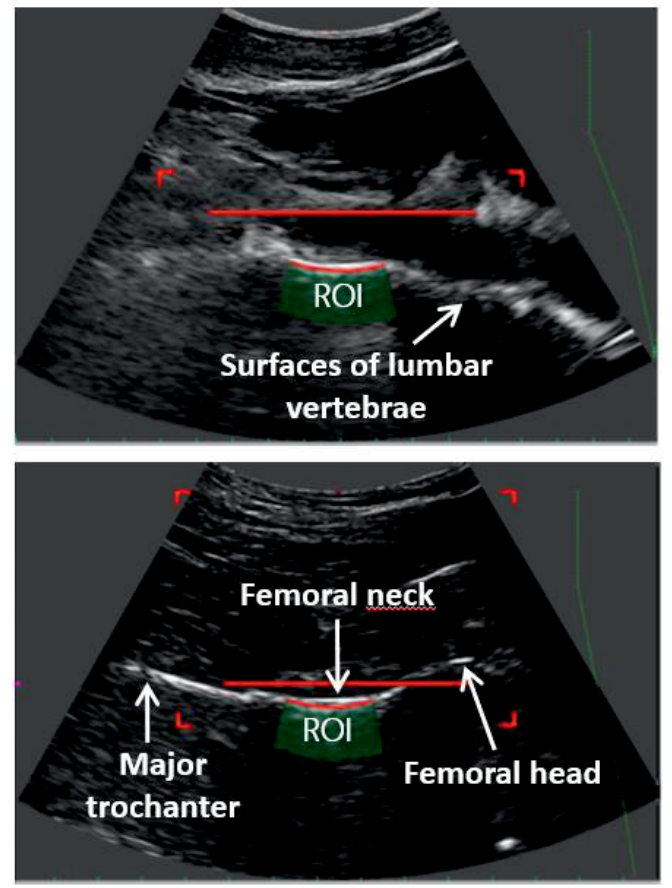

Figure 3. Visualisation of the anatomical sites examined during REMS densitometry, with regions of interest (ROI) having been marked. (Own modification of the materials made available by courtesy of the Institute of Clinical Physiology of the Italian National Research Council).

operator maintains the placement of the probe throughout the measurement time, i.e. 40 seconds. When the scan is ended, an automatic algorithm processes the signals and calculates the densitometry result. It takes 1-2 minutes for the lumbar spine and about 1 minute for the hip. Depth, focus and other visualisation parameters are set through the user interface, which requires an appropriate training. The aim is to select the parameters in such a way that the surface of the tested bone is located in the ultrasound beam focal zone and, at the same time, at about halfway through the image depth $[16,19]$. A visualisation of the anatomical sites examined during REMS densitometry has been shown in Figure 3 .

\section{WHAT DOES THE "REMS" ACRONYM MEAN?}

It may be predicted that the new BMD assessment method will come to be known to clinicians as "densitometry by REMS" or shorter "REMS densitometry". However, each letter of this acronym provides some information on the physical basis of the radiofrequency echographic multi-spectrometry. Spectrometric methods are a wide range of methods that examine the structure and properties of the matter on the basis of spectra, resulting from 
the interaction of various forms of radiation, waves or molecules on the matter [22]. The REMS-analysed spectra are the result of the ultrasound interaction with tissues, which places the method among the acoustic spectrometry ones. Given the way ultrasound interacts with the examined bone, i.e. its reflection or, more precisely, backscattering — it is possible to speak about acoustic reflection or acoustic backscatter spectrometry. The "multi-" prefix emphasizes the REMS method being based on a complete and complex spectral analysis, i.e. a comprehensive comparison of the ultrasound spectra obtained (considered as a whole) with the spectral reference models. This distinguishes REMS from the QUS techniques based on the evaluation of single, simple spectral phenomena. The adjective "echographic" describes the application of acoustic (sound) waves in the technique. In the Polish medical literature, a loan translation from "echographic" is rarely found and related terms such as "ultrasonographic" or "ultrasonic" are used much more frequently. Both of them (due to the "ultra-" prefix) convey additional information on the acoustic waves frequency. In the view of the authors of this paper, the adjective "ultrasonographic" reflects the character of the REMS method best. It indicates not only the use of ultrasound, but also the fact that the structures evaluated during the measurement are being visualised. The last word of the "REMS" acronym presents the greatest risk of misunderstanding, as it may erroneously suggest the use of radio waves. In fact, "radiofrequency" describes electrical signals, into which the ultrasound echoes returning to the probe are converted. Radiofrequency signals, generated in the device and analysed by the computer, are not to be confused with radiofrequency electromagnetic waves. The latter have nothing to do with the REMS method [16].

\section{CLINICAL SIGNIFICANCE OF REMS DENSITOMETRY}

In 2018, results of the first multi-centre study, evaluating the diagnostic usefulness of REMS in comparison with DXA, were published [23]. It included 1914 post-menopausal women aged 50-71, referred for a DXA scan of the femoral neck and/or the lumbar spine. The objectives of the study were to evaluate the sensitivity, specificity and diagnostic accuracy of REMS in relation to DXA, and the repeatability and reproducibility of the REMS measurements. For this purpose, REMS and DXA densitometry were performed on the patients in the locations according to the doctor's referral. Following strict quality control and the elimination of doubtful results, 1373 femoral neck and 1195 lumbar spine measurements were analysed. The diagnostic sensitivity of REMS in the diagnosis of osteoporosis was $91.5 \%$ for the femoral neck and $91.7 \%$ for the lumbar spine, and the diagnostic specificity was, respectively, $91.8 \%$ and $92.0 \%$. Diagnostic sensitivity and specificity were assessed in two categories: osteoporosis/no osteoporosis. When three densitometric categories (normal value, osteopenia, osteoporosis) were taken into account, REMS had a high diagnostic concordance with DXA: $88.2 \%$ in the femoral neck and $88.8 \%$ in the lumbar spine. A T-score tolerance threshold of 0.3 standard deviation increased this concordance to, respectively, $98.0 \%$ and $97.4 \%$. There was a very strong positive linear correlation between the T-score values obtained by REMS and DXA in both central sites (femoral neck: $r=0.93$; $\mathrm{p}<0.001$; lumbar spine: $\mathrm{r}=0.94 ; \mathrm{p}<0.001$ ). The Bland-Altman plot demonstrated that the diagnostic accuracy of BMD assessment by REMS did not depend on the BMD value, but remained within the whole range of this parameter. The high repeatability of the REMS measurements should be noted. In the quoted study, intra-operator root-mean-square coefficient of variation (RMS-CV) was equal to $0.32 \%$ in the femoral neck and $0.38 \%$ in the lumbar spine. According to the available literature, these values in DXA method are higher and equal to $1.47 \%$ and $1.07-1.34 \%$, respectively. This suggests lower repeatability of DXA measurements and requires further verification in well-designed comparative studies [23].

High diagnostic accuracy of REMS with respect to DXA had previously been demonstrated in single-centre studies. For example, in 342 women aged 51-50, the results of lumbar spine densitometry performed by the two methods were concordant in $91.1 \%$. In another group of 377 women aged 61-70 years, the diagnostic concordance of the BMD assessment at the hip was $94.7 \%$ [19]. A relatively low repeatability of REMS measurements was observed in these studies, especially in the former one. On the one hand, it could have been related to the ongoing optimisation of the diagnostic algorithm. On the other hand, the quality control of the measurements was 
Table 1. Diagnostic data of REMS densitometry assessed in clinical conditions [16, 19, 23]

\begin{tabular}{|l|c|c|c|c|}
\hline \multirow{2}{*}{} & \multicolumn{2}{|c|}{ Femoral neck } & \multicolumn{2}{c|}{ L1-L4 vertebrae } \\
\cline { 2 - 5 } & {$[\mathbf{2 3} \mathbf{n}=\mathbf{1 3 7 3}$} & {$[\mathbf{1 9 ]} \mathbf{n}=\mathbf{3 7 7}$} & {$[\mathbf{2 3} \mathbf{n}=\mathbf{1 1 9 5}$} & [16] $\mathbf{n}=\mathbf{3 4 2}$ \\
\hline Diagnostic sensitivity* & $91.5 \%$ & - & $91.7 \%$ & - \\
\hline Diagnostic specificity* & $91.8 \%$ & - & $92.0 \%$ & - \\
\hline Diagnostic accuracy* & $88.2 \%$ & $94.7 \%$ & $88.8 \%$ & $91.1 \%$ \\
\hline Intra-op. RMS-CV & $0.32 \%$ & $0.75 \%$ & $0.38 \%$ & $2.95 \%$ \\
\hline LSC† & $0.88 \%$ & $0.007 \mathrm{~g} / \mathrm{cm}^{2}$ & $1.05 \%$ & $0.078 \mathrm{~g} / \mathrm{cm}^{2}$ \\
\hline Inter-op. RMS-CV & $0.48 \%$ & $0.36 \%$ & $0.54 \%$ & $4.0 \%$ \\
\hline
\end{tabular}

* it was evaluated against the dual energy X-ray absorptiometry; $†$ evaluated at a $95 \%$ confidence interval according to the algorithm of the International Society of Clinical Densitometry; Intra-op. RMS-CV — intra-operator root-mean-square coefficient of variation, i e. a measure of repeatability; Inter-op. RMS-CV - inter-operator root-mean-square coefficient of variation, i e. a measure of reproducibility; LSC — least significant change

not as strict as in the multi-centre study mentioned above. Data on the clinical relevance of REMS densitometry have been summarised in Table 1.

It is impossible to deny that the appropriate performance of REMS and DXA densitometry increases the concordance of the obtained results $[23,24]$. Among the main reasons for doubtful results in the REMS method are the depth and focus at suboptimal settings. The addition of an automatic tool for optimising both parameters during the measurement is being considered by the authors of the method [23]. It should be noted that small discrepancies in DXA and REMS results do not have to argue against the latter. It is suspected that the REMS result - as an ultrasound method - may depend to some extent on the qualitative features of bone tissue, which are not assessed by the DXA method, but they significantly affect the risk of fractures. If this were to be the case, certain inaccuracy of REMS in relation to the current gold standard would not be so much a disadvantage of the new method, but a reflection of its better ability to predict fracture risk. These interesting hypotheses need to be verified in well-designed prospective studies, which will assess the relationship between REMS results and fracture risk. Prospective serial measurements of BMD by two methods in one group of patients would also be of great value. This would allow to verify the differences in precision of REMS and DXA in clinical conditions [23]. What must be taken into account is the fact that, in terms of result comparability, the REMS method is based on an automatic algorithm, designed to eliminate doubtful results - whether due to the measurement technique or the properties of the tested area. This process in the DXA method depends solely on the skill and experience of the operator. For example, soft tissue calcifications, according to the au- thors of the REMS method, do not cause a false overestimation of BMD values, as is the case in DXA [16]. Given the fact that spectral analysis includes a comparison of the examined area features with the ones of the trabecular bone spectral model and that the appropriate measurement site is at a certain depth below the ROI surface, it may be expected that osteophytes, syndesmophytes or compression fracture areas are similarly omitted. Such an artifact should be omitted by a selective assessment of the more deeply located trabecular bone or by classification of the whole area as non-diagnostic. These considerations are based on the very promising principle of the REMS method. However, there is a need for dedicated research on the effectiveness of the REMS algorithm in recognition of particular types of artifacts. Patients with ankylosing spondylitis or osteoarthritis would be a convenient population for this type of studies.

\section{FDA APPROVAL OF REMS}

In October 2018, the REMS densitometer was approved by the Food and Drug Administration (FDA) under the $510(\mathrm{k})$ procedure, which is equivalent to an FDA clearance in the U.S. market. The device's indications for use, its clinical utility, the method's principle and safety issues were all described in the approval document. The existence of reliable data comparing REMS and DXA was confirmed. Data selected from the FDA approval document for REMS has beeen presented in Table 2.

\section{LIMITATIONS OF THE REMS METHOD}

From the perspective of the authors' two years' experience of using REMS densitometry, some potential limitations of the method may be pointed out. The first one is the difficulty in performing measurements in obese 
Table 2. Selected data from the Food and Drug Administration (FDA) approval document for REMS [21]

\begin{tabular}{|c|c|}
\hline Device name & EchoS \\
\hline Software name & EchoStudio \\
\hline Manufacturer & Echolight S.p.A., Lecce, Italy \\
\hline Measurement technique & Ultrasound \\
\hline Measurement mode & Reflection* \\
\hline Measurement location & $\begin{array}{l}\text { - Lumbar spine } \\
\text { - Femoral neck }\end{array}$ \\
\hline Diagnostic parameters & $\begin{array}{l}\text { - } \text { BMD }_{\text {REMS }} \\
\text { - T-score } \\
\text { - Z-score } \\
\text { - Fracture risk assessment with the integrated FRAX }{ }^{\circledR} \text { algorithm }\end{array}$ \\
\hline Comparison with DXA & $\begin{array}{l}\text { - The } B M D_{\text {REMS }} \text { and } B M D_{D X A} \text { values are expressed in } \mathrm{g} / \mathrm{cm}^{2} \\
\text { - The } B M D_{\text {REMS }} \text { and } B M D_{D X A} \text { values have high correlation } \\
(r=0.94 \text { for lumbar spine; } r=0.93 \text { for femoral neck) } \dagger \\
\text { - The } B M D_{\text {REMS }} \text { and } B M D_{D X A} \text { measurements have comparable precision } \\
\text { - SEE } B M D_{\text {REMS }} v S B M D_{D X A} \text { is: } 0.044 \mathrm{~g} / \mathrm{cm}^{2} \text { in the lumbar spine } \\
\text { and } 0.038 \mathrm{~g} / \mathrm{cm}^{2} \text { in the femoral neck }\end{array}$ \\
\hline Reference databases & $\begin{array}{l}\text { - Proprietary internal database for the } B_{M D} D_{\text {REMS }} \text { evaluation } \\
\text { - NHANES reference database to calculate T-Score and Z-score on the basis of BMD } \\
\text { REMS }\end{array}$ \\
\hline $\begin{array}{l}\text { Standards of safety, quality, } \\
\text { electromagnetic compatibility and } \\
\text { biocompatibility have been met }\end{array}$ & $\begin{array}{l}\text { EN 60601-1 } \\
\text { EN 60601-2-37 } \\
\text { IEC 62304:2006 } \\
\text { ISO 10993-1:2009 } \\
\text { IEC 60601-1-2:2014 }\end{array}$ \\
\hline
\end{tabular}

*to be more precise: backscatter; †Pearson correlation coefficient; BMD — bone mineral density; DXA — dual-energy X-ray absorptiometry; NHANES — National Health and Nutrition Examination Survey; REMS — radiofrequency echographic multi-spectrometry; SEE — standard error of the estimate

patients. The maximum scan depth, that is regulated by the "depth" parameter, is $210 \mathrm{~mm}$ for the lumbar spine and $150 \mathrm{~mm}$ for the hip. This is the maximum distance between the ultrasound probe and the surface of the evaluated bone. In the case of obese patients, this distance is sometimes insufficient, especially in terms of the visualisation of vertebrae through the abdominal wall. The issue was assessed in one study, including 382 overweight or obese women aged 45-80 years. The diagnostic accuracy of REMS against DXA in the lumbar spine in patients aged 45-65 years was $81.5 \%$ [25]. In the multi-centre study cited above, this value was $88.8 \%$, which may confirm technical difficulties in patients with excessive body weight [23]. A more significant decrease in the diagnostic accuracy of REMS (69.6\%) was observed in obese or overweight women aged 66-80 years. Due to the possible coexistence of osteoarthritic lesions, which could have disturbed the correlation between the results of both methods by affecting the DXA result to a greater extent, these data are difficult to interpret [25]. The second potential limitation of REMS, as an ultrasound method, includes issues related to vertebral visualisation in patients shortly after eating. So far, this issue has not been addressed in the literature. In the authors' personal experience, artifacts related to the gastrointestinal system can make REMS performance difficult, especially in patients with peristaltic impairment, e.g. in systemic sclerosis. In such rare cases, a rescan may be helpful, with the patient prepared as for abdominal ultrasound.

So far, no prospective studies assessing the relationship between the REMS result and the risk of fracture have been published, and all evidence of the method's usefulness is related to Caucasian women. This justifies the need for further studies, especially prospective ones, including the population of men and people of different ethnic backgrounds [23].

\section{SUMMARY}

Given the current clinical data, REMS densitometry can be recommended for the diagnosis of osteoporosis. The main advantages of this promising diagnostic method are high diagnostic concordance with DXA, good measurement precision, mobility of equipment, automatic elimination of doubtful results and its non-ionizing nature. To the authors' best knowledge, this is the first Polish paper on REMS densitometry. 


\section{References}

1. Consensus development conference: Diagnosis, prophylaxis, and treatment of osteoporosis. The American Journal of Medicine. 1993; 94(6): 646-650, doi: 10.1016/00029343(93)90218-e.

2. Hernlund $E$, Svedbom $A$, Ivergård $M$, et al. Osteoporosis in the European Union: medical management, epidemiology and economic burden. A report prepared in collaboration with the International Osteoporosis Foundation (IOF) and the European Federation of Pharmaceutical Industry Associations (EFPIA). Arch Osteoporos. 2013; 8: 136, doi: 10.1007/s11657-013-0136-1, indexed in Pubmed: 24113837.

3. Kanis JA, Cooper C, Rizzoli R, et al. European guidance for the diagnosis and management of osteoporosis in postmenopausal women. Osteoporos Int. 2019; 30(1): 3-44, doi: 10.1007/s00198-018-4704-5, indexed in Pubmed: 30324412.

4. Ensrud KE, Lui LY, Taylor BC, et al. A comparison of prediction models for fractures in older women: is more better? Arch Intern Med. 2009; 169(22): 2087-2094, doi: 10.1001/archinternmed.2009.404, indexed in Pubmed: 20008691.

5. Hillier TA, Cauley JA, Rizzo JH, et al. WHO absolute fracture risk models (FRAX): do clinical risk factors improve fracture prediction in older women without osteoporosis? J Bone Miner Res. 2011; 26(8): 1774-1782, doi: 10.1002/jbmr.372, indexed in Pubmed: 21351144.

6. Marshall D, Johnell 0 , Wedel $H$. Meta-analysis of how well measures of bone mineral density predict occurrence of osteoporotic fractures. BMJ. 1996; 312(7041): 1254-1259, doi: 10.1136/bmj.312.7041.1254, indexed in Pubmed: 8634613.

7. Kanis JA. Assessment of fracture risk and its application to screening for postmenopausal osteoporosis. Report of a WHO Study Group. World Health Organ Tech Rep Ser. 1994; 843(6): 1-129, indexed in Pubmed: 7941614.

8. Faulkner KG. The tale of the T-score: review and perspective. Osteoporos Int. 2005; 16(4): 347-352, doi: 10.1007/s00198-004-1779-y, indexed in Pubmed: 15565352.

9. Leszczyński P, Mariusz K, Pawlak-Buś K, et al. Diagnostyka i leczenie osteoporozy — zalecenia Polskiego Towarzystwa Reumatologicznego 2015. Forum Reumatol. 2015; 1(1): 12-24.

10. Schousboe JT, Shepherd JA, Bilezikian JP, et al. Executive summary of the 2013 International Society for Clinical Densitometry Position Development Conference on bone densitometry. J Clin Densitom. 2013; 16(4): 455-466, doi: 10.1016/j.jocd.2013.08.004, indexed in Pubmed: 24183638.

11. Lorente Ramos RM, Azpeitia Armán J, Arévalo Galeano $\mathrm{N}$, et al. Dual energy X-ray absorptimetry: fundamentals, methodology, and clinical applications. Radiologia. 2012; 54(5): 410-423, doi: 10.1016/j.rx.2011.09.023, indexed in Pubmed: 22285678.

12. Tatoń G, Rokita E, Korkosz M, et al. The ratio of anterior and posterior vertebral heights reinforces the utility of DXA in assessment of vertebrae strength. Calcif Tissue Int. 2014;
95(2): 112-121, doi: 10.1007/s00223-014-9868-1, indexed in Pubmed: 24854155.

13. Kyriakos G, Vidal-Casariego A, Fernández-Martínez MN, et al. Is vitamin $D$ deficiency being considered in the differential diagnosis of osteoporosis in routine practice? Endocrinol Nutr. 2016; 63(1): 49-50, doi: 10.1016/j.endonu.2015.09.002, indexed in Pubmed: 26522975.

14. Szafrański T, Kostyk T, Leszczyński P. Interpretation of DXA densitometric and morphometric examinations. Menopausal Review. 2012; 5: 392-395, doi: 10.5114/pm.2012.31465.

15. Pisani P, Renna MD, Conversano F, et al. Screening and early diagnosis of osteoporosis through $\mathrm{X}$-ray and ultrasound based techniques. World J Radiol. 2013; 5(11): 398-410, doi: 10.4329/wjr.v5.111.398, indexed in Pubmed: 24349644.

16. Conversano F, Franchini R, Greco A, et al. A novel ultrasound methodology for estimating spine mineral density. Ultrasound Med Biol. 2015; 41(1): 281-300, doi: 10.1016/j.ultrasmedbio.2014.08.017, indexed in Pubmed: 25438845.

17. Casciaro S, Conversano F, Pisani P, et al. New perspectives in echographic diagnosis of osteoporosis on hip and spine. Clin Cases Miner Bone Metab. 2015; 12(2): 142-150, doi: $10.11138 / \mathrm{ccmbm} / 2015.12 .2 .142$, indexed in Pubmed: 26604940.

18. https://www.echolightmedical.com (17.05.2019).

19. Casciaro S, Peccarisi M, Pisani P, et al. An advanced quantitative echosound methodology for femoral neck densitometry. Ultrasound Med Biol. 2016; 42(6): 1337-1356, doi: 10.1016/j.ultrasmedbio.2016.01.024, indexed in Pubmed: 27033331.

20. Peccarisi M, Bottai V, Greco A, et al. In-vitro study of human proximal femur microstructure: analysis of the relationship between micro-computed tomography data and quantitative ultrasound parameters. IET Science, Measurement \& Technology. 2016; 10(3): 193-199, doi: 10.1049/iet-smt.2015.0041.

21. U.S. Food \& Drug Administration (2018): Echolight S.p.a. EchoS 510(K) Premarket Notification. https:// www.accessdata.fda.gov/cdrh_docs/pdf18/K180516.pdf (17.05.2019).

22. Skoog DA, Holler FJ, Crouch SR. An Introduction to Spectrometric Methods. Principles of Instrumental Analysis. Wydanie siódme. Cengage Learning, Boston 2018: 120.

23. Di Paola M, Gatti D, Viapiana 0, et al. Radiofrequency echographic multispectrometry compared with dual X-ray absorptiometry for osteoporosis diagnosis on lumbar spine and femoral neck. Osteoporos Int. 2019; 30(2): 391-402, doi: 10.1007/s00198-018-4686-3, indexed in Pubmed: 30178159.

24. Muratore M, Conversano F, Pisani P, et al. Accurate assessment of femoral echosound approach performance through DXA error analysis. Ann Rheum Dis. 2017; 76(Suppl2): 1353.

25. Casciaro S, Pisani P, Quarta E, et al. Innovative ultrasound approach to estimate spinal mineral density: diagnostic assessment on overweight and obese women. IET Science, Measurement \& Technology. 2016; 10(1): 1-9, doi: 10.1049/iet-smt.2015.0056. 


\section{Densytometria kości metodala ultrasonograficznej multispeltrometrii częstotliwości radiowej (REMS) W rozpoznawaniu osteoporozy}

Artykuł jest tłumaczeniem pracy: Iwaszkiewicz C., Leszczyński P., Bone densitometry by radiofrequency echographic multi-spectrometry (REMS) in the diagnosis of osteoporosis. Forum Reumatol. 2019 tom 5, nr 2: 81-88.

Należy cytować wersję pierwotną.

Piśmiennictwo znajduje się na stronie 88.

\section{STRESZCZENIE}

W artykule podsumowano aktualną wiedzę na temat nowej metody densytometrii kości, zwanej ultrasonograficzną multispektrometrią częstotliwości radiowej (REMS). To oparte na zastosowaniu ultradźwięków podejście diagnostyczne umożliwia ocenę gęstości mineralnej kości (BMD, bone mineral density) w biodrze i części lędźwiowej kręgosłupa. Podczas densytometrii REMS automatyczny algorytm wykonuje serię analiz spektralnych i statystycznych, obejmujących obrazy ultrasonograficzne i odpowiadające im „surowe” (nieprzetworzone) sygnały częstotliwości radiowej. Pozwala to na identyfikację właściwego obszaru zainteresowania (ROI, region of interest) i obliczenie standardowych wskaźników densytometrycznych: BMD, T-score, Z-score. Obrazy niediagnostyczne i artefakty są automatycznie odrzucane, co zmniejsza ryzyko wyników fałszywych. Opublikowane ostatnio badanie wieloośrodkowe potwierdziło wysoką czułość, swoistość i dokładność diagnostyczną tej innowacyjnej metody rozpoznawania osteoporozy. Zgodnie z wiedzą autorów, jest to pierwsze opracowanie w języku polskim poświęcone densytometrii REMS.

Forum Reumatol. 2019, tom 5, nr 2: 89-96

Słowa kluczowe: osteoporoza; gęstość kości; ultrasonografia

\section{WSTEPP}

Osteoporoza jest układową chorobą szkieletu charakteryzującą się niską masą kostną i pogorszeniem mikroarchitektury tkanki kostnej, czego konsekwencją jest wzrost łamliwości kości i podatności na złamania [1]. Złamania osteoporotyczne zwykle są następstwem urazów niskoenergetycznych — jak upadek z własnej wysokości - lub występują bez uchwytnego urazu. Stanowią one częstą przyczynę bólu, niepełnosprawności, obniżenia jakości życia i wzrostu śmiertelności chorych, co czyni osteoporozę istotnym problemem społecznym. Szacuje się, że w 2010 roku w samej Unii Europejskiej 22 miliony kobiet i 5,5 miliona mężczyzn spełniało densytometryczne kryterium osteoporozy, a liczba nowych złamań niskoenergetycznych wyniosła 3,5 miliona [2]. Celem leczenia osteoporozy jest zapobieganie złamaniom (pierwszemu lub kolejnym), głównie poprzez zwiększenie wytrzymałości mechanicznej kości i zmniejszenie ryzyka upadków. Ze względu na długotrwały bezobjawowy przebieg kliniczny diagnostyka osteoporozy opiera się na indywidualnej ocenie ryzyka złamań. Na tej samej podstawie podejmowane są decyzje terapeutyczne [3].

\section{ROLA BMD W DIAGNOSTYCE OSTEOPOROZY}

Jednym z najsilniejszych czynników ryzyka złamań jest gęstość mineralna kości (BMD, bone mineral density) oceniana $\mathrm{w}$ badaniu
Adres do korespondencji: dr hab. n. med. Piotr Leszczyński, prof. UM Katedra Reumatologii i Rehabilitacji Uniwersytetu Medycznego im. Karola Marcinkowskiego w Poznaniu

e-mail: piotr_leszczynski@wp.pl 
densytometrycznym [4, 5]. Związek BMD ze wzrostem ryzyka złamań jest tak samo silny, jak zależność między nadciśnieniem tętniczym a ryzykiem udaru mózgu [6]. Dokładnie 25 lat temu międzynarodowa grupa ekspertów, działając przy wsparciu Światowej Organizacji Zdrowia, ogłosiła pionierski raport na temat osteoporozy. Dokument ten stanowi źródło obowiązującego do dziś densytometrycznego kryterium osteoporozy [7]. Stosowana w kryterium wartość T-score odpowiada liczbie odchyleń standardowych, jaka różni BMD ocenioną u pacjenta od średniej w referencyjnej populacji młodych dorosłych. Wskaźnik obliczany analogicznie, lecz względem populacji dopasowanej do pacjenta w zakresie płci i wieku, nosi nazwę Z-score. Zastąpienie bezwzględnej wartości BMD wskaźnikiem statystycznym miało ułatwić interpretację wyników i zmniejszyć wpływ aparatu na wynik densytometrii [8]. Na podstawie wartości T-score i historii przebytych złamań autorzy raportu wyróżnili cztery kategorie:

- wartość prawidłowa ( $\mathrm{T}$-score $\geq-1,0$ )

- osteopenia $(-2,5<\mathrm{T}$-score $<-1)$

- osteoporoza ( $\mathrm{T}$-score $\leq-2,5)$

- ciężka osteoporoza ( $\mathrm{T}$-score $<-2,5$ i złamanie osteoporotyczne).

Warto uściślić, że cytowany raport dotyczył tylko osteoporozy pomenopauzalnej, a powyższe kategorie miały służyć do celów epidemiologicznych. Kryterium T-score trafiło jednak na podatny grunt oczekiwań klinicystów, dla których pojęciowe definicje osteoporozy były bezużyteczne. W tych warunkach, drogą praktyki klinicznej, próg T-score $\leq-2,5$ stał się kryterium diagnostycznym. Początkowo stosowano je u kobiet po menopauzie, a z czasem także u mężczyzn po 50. roku życia [3, 8]. Wbrew częstemu przekonaniu, raport z 1994 roku nie faworyzował jednej metody densytometrii lub obszaru badanego. Wskazano w nim trzy metody badawcze, spełniające warunki dobrego testu przesiewowego: jednowiązkową absorpcjometrię fotonową, jednowiązkową absorpcjometrię rentgenowską i dwuwiązkową absorpcjometrię rentgenowską (DXA, dual-energy X-ray absorptiometry). Z kolei wybór lokalizacji badanej miał wynikać z celu densytometrii lub programu przesiewowego [7]. Obecnie można stwierdzić, że próbę czasu przetrwała tylko metoda DXA, a największą wartość diagnostyczną i rokowniczą ma ocena BMD w biodrze lub części lędźwiowej kręgosłupa, zwanych lokalizacjami centralnymi. W ich obrębie wyróżnia się wła- ściwe obszary badane, czyli tak zwane obszary zainteresowania (ROI, region of interest): szyjkę kości udowej (femoral neck), cały bliższy koniec kości udowej (total hip/total proximal femur) i kręgi L1-L4 [9, 10]. Spośród wyróżnionych w raporcie kategorii w użyciu pozostaje tylko kryterium osteoporozy oraz wartości prawidłowej. Pojęcie „osteopenii” nie jest dziś kategorią kliniczną i zgodnie z pierwotnym zamiarem jego twórców powinno pozostać kategorią epidemiologiczną. Bezużyteczne okazało się kryterium „ciężkiej osteoporozy” — w obecności złamań trudno uzależniać ocenę ciężkości choroby od jakiegokolwiek progu BMD [3]. Podobnie, u pacjentów po przebytym złamaniu niskoenergetycznym można rozpoznać osteoporozę bez spełnienia kryterium densytometrycznego. W tych przypadkach pomiar BMD pozostaje jednak cennym narzędziem w monitorowaniu leczenia [9]. Zgodnie z wytycznymi Międzynarodowego Towarzystwa Densytometrii Klinicznej (ISCD, International Society for Clinical Densitometry), wartość T-score szyjki kości udowej i obszaru „total hip” u pacjentów obojga płci obliczana jest względem referencyjnej populacji kobiet rasy kaukaskiej w wieku 20-29 lat, utworzonej w ramach III Narodowego Programu Badań Stanu Zdrowia i Odżywiania USA (NHANES, National Health and Nutrition Examination Survey III). Z kolei T-score kręgów lędźwiowych ustala się na podstawie bazy referencyjnej zapewnionej przez producenta densytometru [10].

\section{METODY DXA I QUS}

W metodzie DXA, na podstawie stopnia osłabienia promieniowania rentgenowskiego po przejściu przez obszar badany, ocenia się zawartość minerału kostnego (BMC, bone mineral content), a następnie z ilorazu BMC [g] i rzutowanej powierzchni kości $\left[\mathrm{cm}^{2}\right]$ oblicza się wartość BMD $\left[\mathrm{g} / \mathrm{cm}^{2}\right]$. Rzutowana powierzchnia kości, czyli pole powierzchni rzutu badanego obszaru na płaszczyznę, zastępuje tu niejako jej objętość, niemożliwą do oceny w dwuwymiarowym badaniu DXA. Wartość BMD $\left[\mathrm{g} / \mathrm{cm}^{2}\right]$ nie jest więc gęstością w sensie fizycznym $\left[\mathrm{g} / \mathrm{cm}^{3}\right]$ i bywa nazywana powierzchniową gęstością mineralną kości (areal bone mineral density) [11, 12]. W warunkach prawidłowej mineralizacji macierzy kostnej, jak na przykład w osteoporozie, wartości BMD i BMC są odzwierciedleniem masy kostnej [13, 14].

Metoda DXA, uważana za złoty standard oceny BMD w praktyce klinicznej, nie jest wol- 
na od ograniczeń, które zmniejszają jej dostępność i przydatność do badań przesiewowych. Wśród najważniejszych ograniczeń metody DXA należy wskazać: wysokie ryzyko wyników fałszywie negatywnych, konieczność obsługi przez wysoko wykwalifikowany personel, niską mobilność sprzętu, wysokie koszty, możliwość oceny tylko przy określonym ułożeniu ciała pacjenta oraz wymogi organizacyjno-prawne związane $\mathrm{z}$ promieniowaniem jonizującym [14-16].

Nadzieje na poprawę wykrywalności osteoporozy wiązano z ultrasonografią ilościową (QUS, quantitative ultrasound), która omija większość ograniczeń DXA, ale nie może być uznana za jej alternatywę. Dostępne techniki QUS działają w trybie transmisyjnym, opartym na analizie impulsów fali ultradźwiękowej po przejściu przez obszar badany. W tym układzie widma akustyczne oceniane są pod kątem konkretnych zjawisk ilościowych, stanowiących efekt oddziaływania ultradźwięków z tkanką kostną. Najczęściej analizowane parametry to szerokopasmowe tłumienie ultradźwięków (broadband ultrasound attenuation) i prędkość rozchodzenia się fali dźwiękowej (speed of sound). W ostatnich latach rośnie zainteresowanie technikami QUS o charakterze rozproszeniowym, które z założenia mają dostarczać więcej informacji o mikroarchitekturze tkanki kostnej. Techniki te bazują na ocenie ilościowej ech, które powracają do głowicy wskutek rozproszenia wstecznego ultradźwięków przez obszar badany. Podobnie do technik transmisyjnych, techniki rozproszeniowe QUS bazują na ocenie pojedynczych zjawisk spektralnych, jak współczynnik rozproszenia wstecznego (backscatter coefficient) czy przesunięcie środka ciężkości widma (spectral centroid shift). Każdy tego rodzaju parametr posiada swoje zalety i ograniczenia. Trzeba podkreślić, że choć wskaźniki akustyczne oznaczane w badaniach QUS mogą wykazywać istotny związek $\mathrm{z}$ wartością BMD, ryzykiem złamań czy cechami mikroarchitektury tkanki kostnej, to żadne $\mathrm{z}$ tych badań nie jest odpowiednikiem oceny densytometrycznej. Aktualnie dostępne techniki QUS nie pozwalają też na ocenę kości w lokalizacjach centralnych $[15,17]$.

\section{ZASADA METODY REMS}

Odpowiedzią na ograniczenia DXA i QUS jest ultrasonograficzna multispektrometria częstotliwości radiowej (REMS, radiofrequency echographic multi-spectrometry)

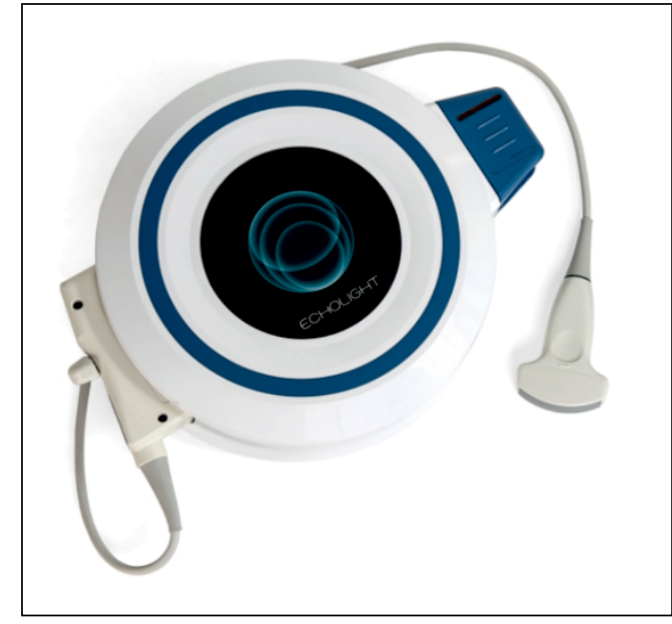

Rycina 1. Densytometr REMS (Echolight S.p.A., Włochy) [18]

- nowa metoda oceny ilościowej kości, stanowiąca przedmiot niniejszego opracowania. Badanie REMS, choć opiera się wyłącznie na oddziaływaniu fal ultradźwiękowych $z$ tkanką kostną, umożliwia ocenę BMD w g/cm² i stanowi pomiar densytometryczny porównywalny z DXA. Ocenę BMD metodą REMS wykonuje się w lokalizacjach centralnych: w biodrze i kręgosłupie lędźwiowym (L1-L4). Z tych powodów densytometria REMS nie jest zaliczana do grupy QUS, a jej postrzeganie w literaturze kształtuje się niejako w opozycji do tych technik $[15,17]$.

Densytometr REMS jest niewielkim aparatem ultrasonograficznym wyposażonym w 128-elementową głowicę typu convex o częstotliwości 3,5 MHz (ryc. 1). Autorskie oprogramowanie zapewnia interfejs użytkownika i algorytm diagnostyczny, stąd konieczność połączenia aparatu z komputerem. Oprócz wersji stacjonarnej, producent oferuje zestaw przenośny, zawierający densytometr i laptop w specjalnie zaprojektowanej walizce (ryc. 2). Zapewnia to dużą mobilność sprzętu. Podczas pomiaru impulsy fali ultradźwiękowej emitowane przez głowicę ulegają wstecznemu rozproszeniu przez tkankę kostną i w formie ech powracają do głowicy. W aparacie echa ultradźwięków zamieniane są na sygnały elektryczne o częstotliwości radiowej ( $\mathrm{RF}$, radiofrequency). Integralna ocena obrazu ultrasonograficznego i „surowych” (nieprzetworzonych) sygnałów RF przez automatyczny algorytm umożliwia identyfikację powierzchni kości badanej i odpowiedniego ROI. Widma ROI są fragmentowane na obszary odpowiadające chrząstce stawowej, kości korowej i kości beleczkowej, a w dalszych obliczeniach 


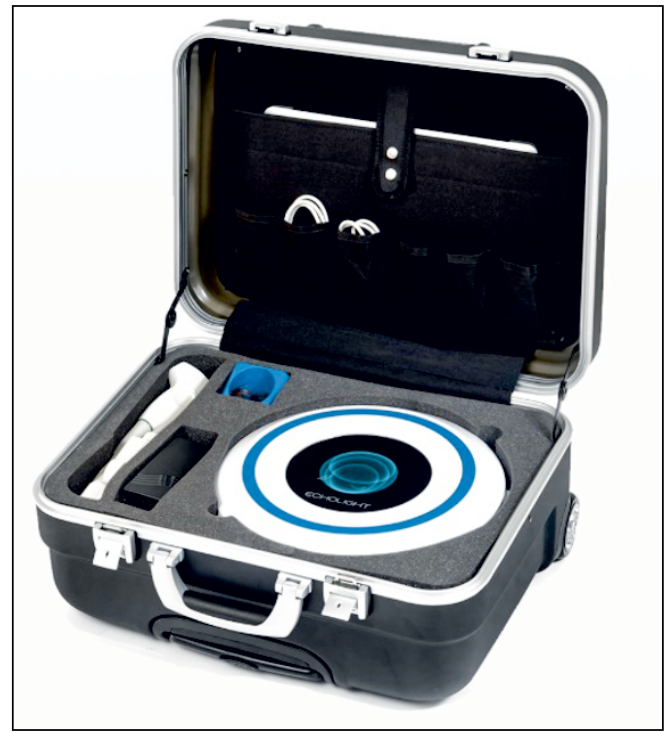

Rycina 2. Densytometr REMS w przenośnym zestawie wyposażonym w laptop (Echolight S.p.A., Włochy) [18]

uwzględniana jest tylko kość beleczkowa. Porównanie widm ROI z referencyjną bazą spektralną prowadzi do obliczenia roboczego wskaźnika O.S. (Osteoporosis Score), a następnie wartości BMD w g/ $\mathrm{cm}^{2}$. W ostatnim etapie - na podstawie referencyjnej bazy NHANES - obliczane są wartości T-score i Z-score [16, 19, 20]. Wynik badania może zawierać ocenę 10-letniego ryzyka złamań, dzięki wbudowanemu kalkulatorowi FRAX ${ }^{\circledR}$ (Fracture Risk Assessment Tool) [21]. Istotną właściwością metody REMS jest automatyczna weryfikacja zgodności cech spektralnych badanego obszaru z modelem kości beleczkowej. Jeśli dany obszar zostanie uznany za niediagnostyczny lub technika pomiaru nie zapewni sygnałów odpowiedniej jakości, to operator nie otrzyma wyniku badania, lecz informację o potrzebie jego powtórzenia. Uzyskanie wyniku REMS części lędźwiowej kręgosłupa wymaga poprawnej oceny BMD co najmniej dwóch kręgów. Automatyczny algorytm jest istotną zaletą metody REMS względem DXA, w której ocena wiarygodności pomiaru zależy wyłącznie od operatora $[16,19]$.

\section{PRZEBIEG BADANIA REMIS}

Badanie w obu lokalizacjach centralnych wykonuje się u pacjenta leżącego na wznak, z kończynami swobodnie ułożonymi wzdłuż ciała. Inne ułożenie pacjenta, na przykład z powodu choroby układu ruchu lub układu nerwowego, nie jest przeciwwskazaniem do wykonania densytometrii REMS. W takich przypadkach niestandardowe ułożenie głowicy może umożliwić ocenę BMD, zależnie od umiejętności i doświadczenia operatora. Podobnym wyzwaniem (lecz nie przeciwwskazaniem) mogą być zmienione stosunki anatomiczne. Badanie REMS rozpoczyna się od przyłożenia głowicy w rzucie ocenianej kości. Kręgi L1-L4 bada się od strony powłok brzusznych, a biodro od strony przedniej powierzchni uda. Na skórę pacjenta (lub głowicę aparatu) nanoszona jest uprzednio cienka warstwa żelu do ultrasonografii. Ocenę kręgów lędźwiowych prowadzi się w kolejności od L1 do L4, stopniowo przesuwając głowicę wzdłuż osi kręgosłupa. Ocena jednego kręgu trwa $20 \mathrm{~s}$, a moment zmiany kręgów jest sygnalizowany wizualnie i dźwiękowo przez aparat. Na ekranie ultrasonografu zwykle dostrzega się powierzchnie dwóch lub więcej kręgów jednocześnie, lecz ocena ilościowa dotyczy tylko kręgu położonego centralnie. Badanie biodra wymaga przyłożenia głowicy równolegle do osi szyjkowo-głowowej kości udowej. Po zapewnieniu jednoczesnej wizualizacji głowy, szyjki i krętarza większego kości udowej operator utrzymuje położenie głowicy przez cały czas pomiaru, czyli 40 s. Zakończenie skanowania uruchamia algorytm, który dokonuje obróbki sygnałów i oblicza wynik densytometrii. Zajmuje to od 1 do 2 minut w przypadku kręgosłupa lędźwiowego i około 1 minuty w przypadku biodra. Głębokość pomiaru (depth), ogniskowanie (focus) i inne parametry wizualizacji ustawia się z poziomu interfejsu użytkownika, co wymaga odpowiedniego przeszkolenia. Celem jest taki dobór parametrów, by powierzchnia ocenianej kości znajdowała się w strefie ogniskowania ultradźwięków, a jednocześnie była jak najbliżej połowy głębokości obrazu [16, 19]. Wizualizację obszarów badanych podczas densytometrii REMS przedstawiono na rycinie 3 .

\section{CO OZNACZA AKRONIM „REMS"?}

Można przewidywać, że nowa metoda oceny BMD zaistnieje w świadomości klinicystów jako „densytometria metodą REMS” lub krócej — „densytometria REMS”. Rozwinięcie tego akronimu zapewnia jednak kilka informacji o fizycznych podstawach ultrasonograficznej multispektrometrii częstotliwości radiowej (radiofrequency echographic multi-spectrometry). Metody spektrometryczne to szeroka grupa metod, badających strukturę i właściwości materii na podstawie interpretacji widm (spectra) powstałych wskutek od- 
działywania różnych form promieniowania, fal lub cząsteczek na materię [22]. Widma analizowane w metodzie REMS są skutkiem oddziaływania ultradźwięków z tkankami, co sytuuje ją wśród metod spektrometrii akustycznej. Uwzględniając sposób oddziaływania ultradźwięków z kością badaną - czyli ich odbicie, a dokładniej rozproszenie wsteczne - można mówić o akustycznej spektrometrii odbiciowej lub rozproszeniowej. Przedrostek „multi-” podkreśla bazowanie metody REMS na pełnej, złożonej analizie spektralnej, czyli całościowym porównaniu widm ultradźwiękowych kości badanej ze spektralną bazą referencyjną. Fakt ten odróżnia metodę REMS od technik QUS, opartych na ocenie prostych pojedynczych zjawisk spektralnych. Przymiotnik „echographic" opisuje zastosowanie w metodzie fal akustycznych (dźwiękowych). W polskim piśmiennictwie medycznym rzadko spotyka się jego kalkę językową „echograficzny”, a dużo częściej stosowane są określenia pokrewne: „ultrasonograficzny” lub „ultradźwiękowy”. Oba z nich (dzięki przedrostkowi ultra-) niosą jeszcze dodatkową informację o częstotliwości fal akustycznych. W opinii autorów tego opracowania przymiotnik „ultrasonograficzna" najlepiej oddaje charakter metody REMS. Wskazuje on bowiem nie tylko na zastosowanie ultradźwięków, ale też na fakt wizualizacji ocenianych struktur w trakcie pomiaru. Największe ryzyko nieporozumień niesie ostatni wyraz terminu „REMS”, gdyż może on mylnie sugerować zastosowanie fal radiowych. W rzeczywistości „częstotliwość radiowa" opisuje sygnały elektryczne, na które zamieniane są echa ultradźwięków powracające do głowicy. Sygnałów o częstotliwości radiowej - powstających w aparacie i analizowanych w komputerze - nie należy mylić $z$ falami elektromagnetycznymi o częstotliwości radiowej. Te ostatnie nie mają $z$ metodą REMS nic wspólnego [16].

\section{ZNACZENIE KLINICZNE DENSYTOMETRII REMS}

W 2018 roku ukazały się wyniki pierwszego badania wieloośrodkowego, oceniającego przydatność diagnostyczną REMS w porównaniu z DXA [23]. Uczestniczyło w nim 1914 kobiet po menopauzie w wieku 50-71 lat, skierowanych przez lekarza na badanie DXA szyjki kości udowej i/lub części lędźwiowej kręgosłupa. Cele pracy obejmowały ocenę czułości, swoistości i dokładności diagnostycznej REMS względem DXA oraz ocenę powta-
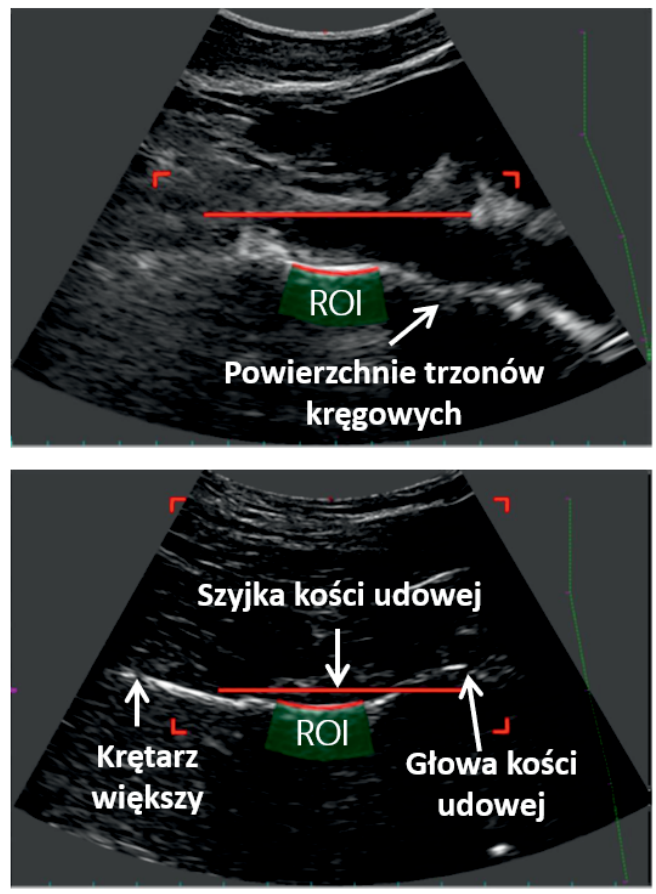

Rycina 3. Obraz lokalizacji badanych z zaznaczonymi obszarami zainteresowania (ROI). (Modyfikacja własna materiałów udostępnionych dzięki uprzejmości Instytutu Fizjologii Klinicznej Włoskiej Krajowej Rady Badań Naukowych)

rzalności i odtwarzalności pomiarów REMS. W tym celu u pacjentek wykonano densytometrię REMS i DXA w lokalizacjach zgodnych ze skierowaniem. Po dokładnej kontroli jakości i eliminacji wyników wątpliwych, przeprowadzono analizę 1373 badań szyjki kości udowej i 1195 badań kręgosłupa lędźwiowego. Czułość diagnostyczna REMS w rozpoznawaniu osteoporozy wyniosła 91,5\% dla szyjki kości udowej i 91,7\% dla kręgosłupa lędźwiowego, a swoistość diagnostyczna wyniosła odpowiednio: 91,8\% i 92,0\%. Czułość i swoistość diagnostyczną oceniono w układzie dwóch kategorii: osteoporoza/brak osteoporozy. Przy uwzględnieniu trzech kategorii densytometrycznych (wartość prawidłowa, osteopenia, osteoporoza), badania REMS i DXA cechowała wysoka zgodność diagnostyczna: $88,2 \%$ w ocenie szyjki kości udowej i 88,8\% w ocenie kręgosłupa lędźwiowego. Próg tolerancji T-score na poziomie 0,3 odchylenia standardowego zwiększał tę zgodność do, odpowiednio, 98,0\% i 97,4\%. Między wartościami T-score uzyskanymi metodą REMS i DXA w obu lokalizacjach centralnych zachodziła bardzo silna korelacja dodatnia o charakterze liniowym (szyjka kości udowej: $\mathrm{r}=0,93$; $\mathrm{p}<0,001$; kręgosłup lędźwiowy: $\mathrm{r}=0,94 ; \mathrm{p}<0,001)$. Jak wskazywał opracowany przez autorów wykres Blanda-Altmana, dokładność diagnostyczna 
oceny BMD metodą REMS nie zależała od wartości BMD, lecz utrzymywała się w całym zakresie tego parametru. Uwagę zwracała wysoka powtarzalność oceny BMD metodą REMS. W cytowanym badaniu błąd precyzji oznaczeń wykonywanych przez jednego operatora (RMS$\mathrm{CV}$, intra-operator root-mean-square coefficient of variation) był równy $0,32 \%$ w szyjce kości udowej i 0,38\% w kręgosłupie lędźwiowym. Zgodnie $\mathrm{z}$ dostępną literaturą, w metodzie DXA wartości te są większe i wynoszą odpowiednio: $1,47 \%$ oraz $1,07-1,34 \%$. Sugeruje to mniejszą powtarzalność pomiarów DXA i wymaga dalszej weryfikacji w dobrze zaprojektowanych badaniach porównawczych [23].

Wysoką dokładność diagnostyczną REMS względem DXA wykazywano już wcześniej w badaniach jednoośrodkowych. Na przykład wśród 342 kobiet w wieku 51-60 lat wynik densytometrii kręgów L1-L4 obiema metodami był zgodny w 91,1\% [16]. W innej grupie 377 kobiet w wieku 61-70 lat zgodność diagnostyczna oceny BMD biodra metodą REMS i DXA wynosiła 94,7\% [19]. W tych badaniach, a zwłaszcza w pierwszym, osiągnięto stosunkowo niskie wskaźniki precyzji. Z jednej strony mogło to być związane z trwającą jeszcze optymalizacją algorytmu diagnostycznego. $\mathrm{Z}$ drugiej, nie zastosowano wówczas tak ścisłej kontroli jakości pomiarów, jaka obowiązywała w cytowanym wyżej badaniu wieloośrodkowym. Dane na temat przydatności klinicznej densytometrii REMS podsumowano w tabeli 1.

Nie ulega wątpliwości, że poprawne wykonywanie densytometrii REMS i DXA zwiększa zgodność uzyskiwanych wyników [23, 24]. Wśród głównych przyczyn wyników wątpliwych w badaniu REMS wskazuje się nieoptymalne ustawienie parametrów głębokości i ognisko- wania przez operatora. Twórcy metody rozważają stworzenie automatycznego narzędzia, służącego do optymalizacji tych parametrów podczas badania [23]. Trzeba zauważyć, że niewielkie rozbieżności w ocenie BMD metodą DXA i REMS nie muszą przemawiać na niekorzyść tej drugiej. Podejrzewa się, że wynik REMS - jako metody ultradźwiękowej - może choć w pewnym stopniu zależeć od jakościowych cech tkanki kostnej, które nie podlegają ocenie metodą DXA, a istotnie wpływają na ryzyko złamań. Gdyby tak było, to pewna niedokładność REMS względem aktualnego złotego standardu okazałaby się nie tyle wadą nowej metody, co odzwierciedleniem jej lepszej zdolności do oceny ryzyka złamań. Te interesujące hipotezy wymagają weryfikacji w dobrze zaprojektowanych badaniach prospektywnych, oceniających związek wyniku REMS z ryzykiem złamań. Dużą wartość miałaby też prospektywna ocena dynamiki BMD dwiema metodami w jednej grupie pacjentów. Pozwoliłoby to zweryfikować różnice precyzji REMS i DXA w warunkach klinicznych [23]. W aspekcie porównywalności wyników należy uwzględnić, że metoda REMS oparta jest na automatycznym algorytmie, mającym eliminować wyniki wątpliwe - czy to ze względu na technikę pomiaru, czy właściwości obszaru badanego. W metodzie DXA proces ten zależy wyłącznie od umiejętności i doświadczenia operatora. Na przykład, zgodnie z zapewnieniem twórców metody REMS, zwapnienia w tkankach miękkich nie powodują fałszywego zawyżenia wartości BMD, jak ma to miejsce w DXA [16]. Biorąc pod uwagę, że ocena spektralna obejmuje porównanie cech badanego obszaru z cechami kości beleczkowej oraz że właściwe miejsce pomiaru znajdu-

Tabela 1. Przydatność diagnostyczna densytometrii REMS oceniona w warunkach klinicznych [16, 19, 23]

\begin{tabular}{|l|c|c|c|c|}
\hline \multirow{2}{*}{} & \multicolumn{2}{|c|}{ Szyjka kości udowej } & \multicolumn{2}{c|}{ Kręgi L1-L4 } \\
\cline { 2 - 5 } & {$[\mathbf{2 3} \mathbf{n}=\mathbf{1 3 7 3}$} & {$[\mathbf{1 9 ]} \mathbf{n}=\mathbf{3 7 7}$} & {$[\mathbf{2 3 ]} \mathbf{n}=\mathbf{1 1 9 5}$} & {$[\mathbf{1 6}] \mathbf{~}=\mathbf{3 4 2}$} \\
\hline Czułość diagnostyczna* $^{*}$ & $91,5 \%$ & - & $91,7 \%$ & - \\
\hline Swoistość diagnostyczna* & $91,8 \%$ & - & $92,0 \%$ & - \\
\hline Dokładność diagnostyczna* & $88,2 \%$ & $94,7 \%$ & $88,8 \%$ & $91,1 \%$ \\
\hline Intra-op. RMS-CV & $0,32 \%$ & $0,75 \%$ & $0,38 \%$ & $2,95 \%$ \\
\hline LSC† & $0,88 \%$ & $0,007 \mathrm{~g} / \mathrm{cm}^{2}$ & $1,05 \%$ & $0,078 \mathrm{~g} / \mathrm{cm}^{2}$ \\
\hline Inter-op. RMS-CV & $0,48 \%$ & $0,36 \%$ & $0,54 \%$ & $4,0 \%$ \\
\hline
\end{tabular}

*oceniano względem dwuwiązkowej absorpcjometrii rentgenowskiej; †oceniano przy 95-procentowym przedziale ufności, zgodnie z algorytmem Międzynarodowego Towarzystwa Densytometrii Klinicznej; Intra-op. RMS-CV (intra-operator root-mean-square coefficient of variation) — błąd precyzji oznaczeń wykonywanych przez tego samego operatora, czyli miara powtarzalności; Inter-op. RMS-CV (inter-operator root-mean-square coefficient of variation) — błąd precyzji oznaczeń wykonywanych przez różnych operatorów, czyli miara odtwarzalności; LSC (least significant change) — najmniejsza znacząca zmiana 
Tabela 2. Wybrane informacje z dokumentu Agencji Żywności i Leków (FDA), aprobującego densytometrię REMS [21]

\begin{tabular}{|c|c|}
\hline Nazwa aparatu & EchoS \\
\hline Nazwa oprogramowania & EchoStudio \\
\hline Producent & Echolight S.p.A., Lecce, Włochy \\
\hline Technika pomiaru & Ultradźwiękowa \\
\hline Tryb pomiaru & Odbiciowy* \\
\hline Lokalizacja badana & $\begin{array}{l}\text { — Część lędźwiowa kręgosłupa } \\
\text { — Biodro }\end{array}$ \\
\hline Uzyskiwane parametry diagnostyczne & $\begin{array}{l}\text { - BMD } \\
\text { - T-score } \\
\text { - Z-score } \\
\text { - Ocena ryzyka złamań w zintegrowanym kalkulatorze FRAX }\end{array}$ \\
\hline Porównanie z DXA & 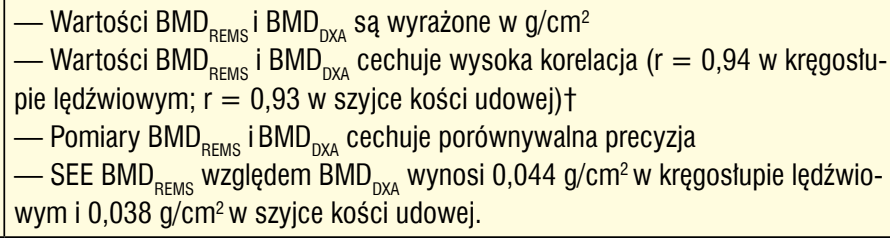 \\
\hline Referencyjne bazy danych & $\begin{array}{l}\text { - autorska baza spektralna do oceny } \mathrm{BMD}_{\text {REMS }} \\
\text { — baza NHANES do obliczania T-score i Z-score na podstawie } \text { BMD }_{\text {REMS }}\end{array}$ \\
\hline $\begin{array}{l}\text { Spełnione normy bezpieczeństwa, } \\
\text { jakości, biokompatybilności i kompaty- } \\
\text { bilności elektromagnetycznej }\end{array}$ & $\begin{array}{l}\text { EN 60601-1 } \\
\text { EN 60601-2-37 } \\
\text { IEC 62304:2006 } \\
\text { ISO 10993-1:2009 } \\
\text { IEC 60601-1-2:2014 }\end{array}$ \\
\hline
\end{tabular}

*a ściślej: rozproszeniowy; †współczynnik korelacji r Pearsona; BMD (bone mineral density) — gęstość mineralna kości; DXA (dual-energy X-ray absorptiometry) — dwuwiązkowa absorpcjometria rentgenowska; NHANES (National Health and Nutrition Examination Survey) — Narodowy Program Badań Stanu Zdrowia i Odżywiania USA; REMS (radiofrequency echographic multi-spectrometry) — ultrasonograficzna multispektrometria częstotliwości radiowej; SEE (standard error of the estimate) — standardowy błąd szacunku

je się na pewnej głębokości pod powierzchnią ROI, można oczekiwać, że podobnie omijane są osteofity, syndesmofity czy obszary złamań kompresyjnych. Automatyczne ominięcie artefaktu powinno nastąpić poprzez selektywną ocenę kości beleczkowej położonej głębiej, lub też uznanie całego obszaru za niediagnostyczny. Wnioskowanie to wynika z niezwykle obiecującego mechanizmu metody REMS. Istnieje jednak potrzeba dedykowanych badań nad skutecznością algorytmu REMS w rozpoznawaniu artefaktów. Dogodną populację dla takich badań stanowiliby pacjenci z zesztywniającym zapaleniem stawów kręgosłupa lub chorobą zwyrodnieniową.

\section{AKCEPTACJA REMS PRZEZ FDA}

W październiku 2018 roku densytometr REMS uzyskał akceptację Agencji Żywności i Leków (FDA, Food and Drug Administration) w procedurze $510(\mathrm{k})$, co jest równoznaczne $\mathrm{z}$ dopuszczeniem do obrotu na rynku amerykańskim. W dokumencie rejestracyjnym opisano przeznaczenie aparatu, jego przydatność kliniczną, zasadę działania i kwestie bezpie- czeństwa. Potwierdzono istnienie wiarygodnych danych porównujących densytometry REMS i DXA. Wybrane informacje $\mathrm{z}$ dokumentu FDA przedstawiono w tabeli 2.

\section{OGRANICZENIA METODY REMS}

Z perspektywy dwuletniego doświadczenia autorów obecnej pracy z densytometrią REMS, można wskazać potencjalne ograniczenia tej metody. Pierwsze to trudności w wykonywaniu pomiarów u pacjentów otyłych. Regulowana parametrem „depth” maksymalna głębokość oceny wynosi $210 \mathrm{~mm}$ dla części lędźwiowej kręgosłupa i $150 \mathrm{~mm}$ dla biodra. Jest to największa odległość, jaka może dzielić głowicę aparatu od powierzchni ocenianej kości. Wśród pacjentów otyłych odległość ta bywa niewystarczająca, zwłaszcza do uwidocznienia kręgów przez powłoki brzuszne. Problem ten oceniono w jednej pracy badawczej, obejmującej 382 pacjentki z nadwagą lub otyłością w wieku 45-80 lat. Dokładność diagnostyczna REMS względem DXA w kręgosłupie lędźwiowym u pacjentek w wieku 45-65 lat wyniosła 81,5\% [25]. W cytowanym wcześniej wieloośrodkowym badaniu wskaź- 
nik ten wynosił $88,8 \%$, co może potwierdzać trudności techniczne $\mathrm{u}$ pacjentów $\mathrm{z}$ nadmierną masą ciała [23]. Istotniejszy spadek dokładności diagnostycznej REMS (do 69,6\%) odnotowano u kobiet $\mathrm{z}$ otyłością lub nadwagą w wieku 66-80 lat. Sa to dane trudne do interpretacji $\mathrm{z}$ uwagi na możliwość współwystępowania zmian zwyrodnieniowych, które - wpływając bardziej na wynik DXA - mogły zaburzyć związek wyników obu metod [25]. Drugim potencjalnym ograniczeniem REMS, jako metody ultradźwiękowej, są problemy z wizualizacją kręgów u pacjentów wkrótce po spożyciu posiłku. Zagadnienie to nie zostało odnotowane w dotychczasowej literaturze. Jak wskazuje osobiste doświadczenie autorów, artefakty związane z układem pokarmowym mogą utrudniać wykonanie REMS zwłaszcza u chorych z zaburzeniami perystaltyki, na przykład w twardzinie układowej. W tych rzadkich przypadkach pomocne bywa powtórzenie badania - po przygotowaniu pacjenta jak do ultrasonografii jamy brzusznej.
Jak dotąd, nie opublikowano żadnych prac prospektywnych oceniających związek wyniku REMS z ryzykiem złamań, a wszystkie dowody na użyteczność tej metody dotyczą kobiet rasy kaukaskiej. Uzasadnia to potrzebę dalszych badań, w tym prospektywnych, obejmujących populację mężczyzn i osób o różnym pochodzeniu etnicznym [23].

\section{PODSUMIOWANIE}

Uwzględniając aktualne dane kliniczne, densytometria REMS może być rekomendowana w rozpoznawaniu osteoporozy. Wysoka zgodność diagnostyczna z DXA, precyzja pomiaru, mobilność sprzętu, automatyczna eliminacja wyników wątpliwych i niezależność od promieniowania rentgenowskiego to główne zalety tej obiecującej metody diagnostycznej. Zgodnie $\mathrm{z}$ wiedzą autorów, jest to pierwsze opracowanie w języku polskim poświęcone densytometrii REMS. 